\title{
Preocupações com a educação physica: o ensino de práticas corporais nas escolas fluminenses (1836 - anos 1850) ${ }^{1}$
}

Victor Andrade de Melo²

\section{Resumo}

Este artigo objetiva discutir as pioneiras experiências de ensino de práticas corporais implementadas em escolas fluminenses entre 1836 e os anos 1850. Como fontes foram utilizados periódicos publicados no Rio de Janeiro. Conclui-se que os intuitos do ensino de práticas corporais eram: auxílio no processo de disciplinarização; contribuição para a saúde e a higiene dos alunos; garantia de formação ampla do educando, tendo em vista sua performance social (o forjar de uma elite nacional). Pode-se sugerir que essas experiências pioneiras já se constituíam claramente como propostas de educação do corpo, compreensíveis a partir das três dimensões sugeridas por Vigarello: modelo adequado de uso do corpo (educação do físico e seu princípio da eficácia); determinados comportamentos públicos desejáveis (educação do espírito e seu princípio da propriedade); inserção do indivíduo, de forma segura, na consolidação de coletivos (princípio da identidade).

\section{Palavras-chave}

História da educação física - Educação do corpo - Práticas corporais.

\section{Concerns about physical education: the teaching of bodily practices in the schools of Rio de Janeiro (1836 - 1850)}

\section{Abstract}

This article aims to discuss the pioneer experiences of teaching bodily practices, implemented in schools of the state of Rio de Janeiro between 1836 and the 1850's. The sources utilized were periodicals published in the same state. Conclusion was that the purposes of teaching

1- Este estudo contou com apoio do Conselho Nacional de Desenvolvimento Científico e Tecnológico (CNPq), da Fundação de Amparo à Pesquisa do Estado do Rio de Janeiro (Faperj) e do Ministério do Esporte (Programa Rede Cedes).

2- Universidade Federal do Rio de Janeiro, Rio de Janeiro, RJ, Brasil. Contato: victor.a.melo@uol.com.br 
corporal practices included: to aid the process of disciplining the bodies; contribute to the health and hygiene of students; guarantee the broader formation of the student, in view of their social performance (to forge a national elite). It may be suggested that these pioneer experiences were already clearly proposed as proposals to educate the body, which can be comprehended based on the three dimensions suggested by Vigarello: an adequate model for the use of the body (physical education and its principle of effectiveness); certain desirable public behaviors (education of the spirit and its principle of property); insertion of the individual, in a safe way, into the consolidation of collectivities (principle of identity).

\section{Keywords}

History of physical education - Body education - Bodily practices.

\section{Introdução}

0 Rio de Janeiro passou por grandes transformações na segunda década do século XIX. $O$ desembarque da família real portuguesa (1808), em razão dos conflitos napoleônicos que assombravam a Europa, subverteu a lógica colonial que impunha barreiras para o desenvolvimento do Brasil. Tendo se tornado sede do Império português, a cidade assistiu a um notável progresso em vários âmbitos, inclusive na sua estrutura urbana e na esfera dos costumes. Nesse cenário, passaram a circular mais intensamente certas novidades que vinham do velho continente (NEVES, 2011; SCHWARCZ, 2011).

A nova movimentação pública, incentivada por um mais bem estruturado mercado ao redor dos entretenimentos, preocupou os dirigentes. Intensificaram-se iniciativas de controle urbano e de restrição a determinados comportamentos (AVELAR, 2010; ALGRANTI, 2011; GOUVÊA, 2012; MELO, 2016c).

Foi nesse contexto que surgiram as pioneiras iniciativas de ensino de práticas corporais institucionalizadas ${ }^{3}$, em espaços escolares e não escolares, no meio civil e no militar. Sintonizadas com o que ocorria na Europa e relacionadas às necessidades relativas à formação de uma elite (a princípio, colonial; a partir de 1822, de caráter nacional), essas experiências, em diferentes graus, articulavam-se com as, na ocasião, ainda recentes preocupações com a educação physica, termo que definia não só o lecionar de exercícios físicos, mas sim as reflexões e intervenções que tinham por fim os cuidados com a saúde e a higiene.

Os protagonistas desses debates eram, em geral, médicos envolvidos com sociedades profissionais, personagens de certo destaque que usualmente veiculavam seus pontos

3- Tenho trabalhado com a ideia de que podemos investigar em conjunto e de forma articulada certas práticas corporais que, embora com peculiaridades, passaram por processos aproximados de constituição de um campo ao seu redor (um processo de institucionalização): os esportes, a educação física, a ginástica, a esgrima, a dança, entre outras. 
de vista em periódicos gerais ou específicos ${ }^{4}$ (MELO; PERES, 2014a). Foi nesse âmbito que surgiram os primeiros posicionamentos sobre a importância das práticas corporais, não poucas vezes considerando a escola como importante espaço de intervenção. ${ }^{5}$ Como observaram Melo e Peres (2014a, p. 77):

A Academia (Imperial de Medicina), inclusive, se pronunciou oficialmente a favor da necessidade do ensino da ginástica nas escolas de instrução primária ${ }^{6}$. A prática materializaria (assim como os demais preceitos da educação física e da higiene, às quais ela estava articulada) a medicalização do cotidiano escolar.

A princípio, a dança foi a que mais notável atenção logrou nas iniciativas de ensino, a reboque de sua grande presença na sociedade fluminense da primeira metade do século XIX (MELO, 2016b; MEL0, 2016a). Todavia, outras práticas começaram a ser aventadas como adequadas para a formação de crianças e jovens, tais como a ginástica, a esgrima, a natação e a equitação, além de corridas e jogos.

Em abril de 1828, alguém não identificado publicou no Jornal do Comércio um anúncio: "precisa-se de um mestre de esgrima” (JORNAL DO COMÉRCIO, 3 abr. 1828, p. 4). Outros semelhantes foram veiculados no mesmo periódico. ${ }^{7}$ Estes são os primeiros indícios de formação de um mercado de ensino de práticas corporais no âmbito não escolar, para além do já citado caso da dança, que desde os anos 1810 vinha se estruturando (MELO, 2016b).

0 primeiro anúncio de alguém a se oferecer para ministrar aulas de ginástica - todos os dias entre 10 e 12 horas, em uma sala localizada na Rua de São Pedro - foi publicado em 1832, no Correio Mercantil. 0 docente não identificado indicava os exercícios ginásticos "para as pessoas de todas as idades, tanto convalescentes, como inválidos" (CORREIO MERCANTIL, 27 jul. 1832, p. 4). ${ }^{8} 0$ intuito era claramente de contribuição para a saúde.

Segundo o professor, a prática seria útil para "remediar e prevenir os funestos males que comumente resultam das tísicas, frouxidão de nervos e fígado, edrupesia, reumatismo, gota e dores de cabeça, em suma para o sistema muscular, e reestabelecimento da saúde" (CORREIO MERCANTIL, 27 jul. 1832, p. 4). Como já observaram Melo e Peres (2014a), naquele momento, mesmo que os médicos reconhecessem os benefícios da ginástica, não se tinha grande clareza de seu potencial, havendo grande multiplicidade de compreensões.

Vale ter em conta que o professor apresentou também outro objetivo da prática: divertimento moral. Pode ser que já tivesse em vista aqueles que apreciavam o que assistiam nos muitos espetáculos apresentados nos palcos da cidade. Naquela primeira metade do século XIX, a ginástica começou a se tornar mais conhecida por estar constantemente

4- Periódicos específicos eram aqueles dedicados exclusivamente às questões da saúde e da higiene, em muitas ocasiões editados pelas sociedades de medicina.

5- Cf., por exemplo, Maia (1840).

6- Trata-se do parecer do Dr. Corrêa de Azevedo sobre a ginástica médica sueca, exarado a partir do relatório Da Utilidade da Ginástica nas Escolas de Ensino Primário, apresentado pelos médicos José Pereira Rego Filho, João Pinto Rego Cesar e João Batista dos Santos (REVISTA MEDICA BRASILEIRA, 1841, p. 143).

7- Cf., por exemplo, Jornal do Comércio, 14 jul. 1829, p. 4.

8- 0 mesmo docente também ofereceu seus serviços no Jornal do Comércio, em termos bem semelhantes, mas com aulas ministradas na Rua do Ouvidor (JORNAL DO COMÉRCI0, 9 ago. 1832, p. 4). 
presente no âmbito do entretenimento, especialmente nos circos, que se tornaram uma das opções de diversão mais valorizadas pela sociedade fluminense (MELO; PERES, 2014a).

Havia mesmo termos em comum entre os diferentes espaços onde se praticava a ginástica. Um exemplo é a Escola Ginástica, na verdade, um grupo de artistas circenses que agradava por suas ousadas performances (JORNAL DO COMÉRCIO, 9 out. 1832, p. 1). ${ }^{9}$ Além disso, como em colégios e salas, não poucas vezes os líderes dessas companhias eram denominados mestres e até professores. É possível que tenham ministrado aulas em seus estabelecimentos ou na residência dos interessados.

Figura 1 - Anúncio de apresentação circense

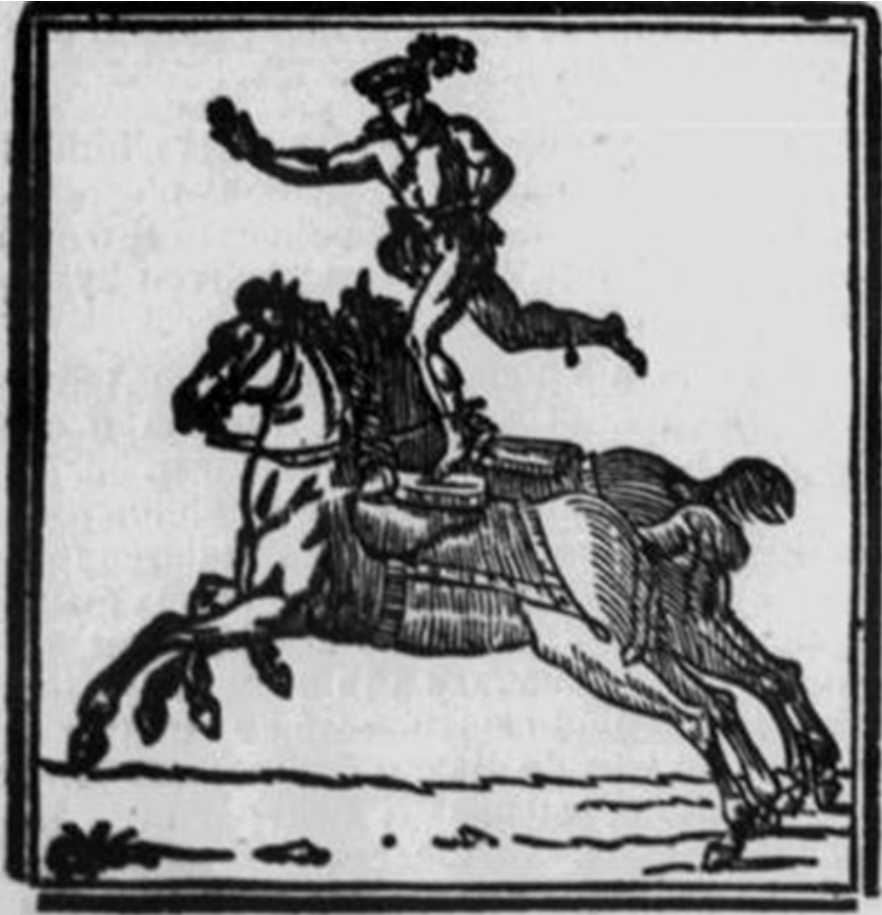
THEATRO DA PAACA MUNICIPAL" DA CIDADE
-DE NITHEROHY, domingo 10 do corrente.

Tendo se reunido as duas companhias sob a direcçáo de José Chiarini, professor de gymnastíca, e de B. G. Mead, professor de equitaçâo. ellas tem a honra de apresentar ao respeitavel publico desta côrte o mais brilhante espectaculo aue thes foi possivel conseguir para the Fonte: Jornal do Comércio, 9 dez. 1837, p. 4.

9- Vale também citar o caso do Circo Chiarini, que, no quartel final do século XIX, apresentava-se como a "verdadeira escola de educação física" (GAZETA DE NOTíCIAS, 26 e 27 nov. 1876, p. 4). 
0 docente que se ofereceu para ministrar aulas em 1832 provavelmente se tratava do sueco Guilherme Luiz de Taube, que atuara nas Forças Armadas nacionais, encerrara seu período de serviço e, casado com uma brasileira, decidiu ficar pelo país, pedindo naturalização em 1831, somente concedida em 1837 (MELO; PERES, 2014a). 0 seu intuito era permanecer como militar. Não sendo possível, resolveu lecionar a ginástica.

Taube entregou à Sociedade de Medicina do Rio de Janeiro um tratado sobre a prática, pedindo avaliação dos facultativos associados, tendo em vista legitimar sua iniciativa docente (MELO; PERES, 2014a). No material, elogiado pelo relator, Dr. Luiz Vicente De-Simoni, membro titular e secretário perpétuo da entidade, o ex-militar "assevera que em diferentes partes do mundo, entre as nações mais clássicas, os exercícios ginásticos têm sido adotados, animados, e muito proveitosos, e como tais julgados necessários pelos médicos" (DE-SIMONI, 1832, p. 414). Taube acabou nomeado, em 1841, o primeiro professor de ginástica do Colégio Pedro II, onde atuou até 1843 (CUNHA JUNIOR, 2008).

Anúncios como o de Taube somente se tornariam usuais no decorrer da segunda metade do século XIX. Os professores - a princípio, mais estrangeiros - ofereciam-se para lecionar diferentes conteúdos, entre os quais a ginástica, sempre apresentada como contributo para a saúde por meio do desenvolvimento físico.

Figura 2-Anúncio de professor

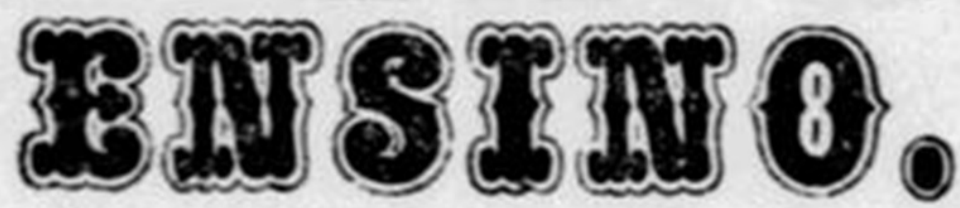

Tim professor competentemente habilitado terá algumas horas disponiveis do 10 de Agosto em diante, que desejara preenchier, dando liçōes de allemão, francez, inglez, latim, ou mathematicas, e mesmo de exercicios gymnastincs, tũo uteis para o desenvolvimente physico dos meninos; as pessoas que desejarem utilisar-se do seu prestimo que1rî̀o dirigir-se, para informaçōes, ú casa dos Srs E. e II. Laemmert, rua da Quitanda n. 77.

Fonte: Jornal do Comércio, 22 jul. 1857, p. 4.

Na transição para os anos 1850, surgiu outra iniciativa de ensino não escolar que merece destaque. 0 espanhol Luiz Guillaume, artista atuante em diversos espetáculos que na cidade se apresentavam - aproveitando as instalações do Circo Olímpico, um dos mais importantes da Corte (MELO; PERES, 2014a) -, abriu a Escola de Equitação e Ginástica (JORNAL DO COMÉRCIO, 9 out. 1849, p. 3). Os exercícios ginásticos eram lecionados, muito provavelmente, à moda do que se exibia nos palcos. 
Figura 3-Anúncio da Escola de Equitação e Ginástica



Fonte: Jornal do Comércio, 9 out. 1849, p. 3.

Vale também lembrar que, a partir dos anos 1860, tornaram-se mais usuais, em clubes e agremiações diversas, a abertura de escolas de ginástica e esgrima. Eram cursos livres à moda do que hoje vemos nas academias. 0 Rio de Janeiro chegou a ter cinco sociedades ginásticas (MELO; PERES, 2014a).

E no cenário escolar? A prestar maior atenção às práticas corporais, foram pioneiras as instituições educacionais militares. Em dezembro de 1810, criou-se a Academia Real Militar. Foi mais uma das iniciativas destinadas a formar profissionais capacitados para dar conta do que necessitava a administração portuguesa no Brasil estabelecida. 0 intuito era preparar oficiais de engenharia (geógrafos e topógrafos) e artilharia. ${ }^{10}$

Mesmo que fossem cursos eminentemente técnicos - expressão das mudanças pelas quais passou o sistema de ensino português -, em diversos momentos se previu a oferta da esgrima para os alunos. Nos jornais, a primeira referência à prática foi encontrada

10- Para mais informações, cf. Mormêllo, 2010. 
em 1816, no Almanaque do Rio de Janeiro (p. 376), ${ }^{11}$ onde podemos saber o nome do encarregado de ministrar as aulas: João Francisco Scipião, português que já lecionava a modalidade em Lisboa.

Tratava-se de aulas extras, não ligadas ao ensino técnico propriamente dito (GAZETA D0 RIO DE JANEIR0, 12 fev. 1817, p. 4). Num primeiro momento, tal oferta era uma expressão da forte relação com o pensamento ilustrado e com as experiências francesas. ${ }^{12}$ Posteriormente, teve a ver com o processo de militarização da instituição, isto é, com o desenvolvimento de uma maior ênfase na formação de oficiais prontos para o combate (MORMÊLLO, 2010).

Foi variável e nem sempre intensa essa preocupação com o aspecto militar (ALVES, 2002). Isso incidia na maior valorização ou não dos exercícios físicos. Por exemplo, com a criação da Escola de Aplicação, em 1855, tornou-se explícita a obrigação de uma prática diária de "Estudo, ou exercício das Armas, ou ginástica, equitação e natação" (MORMÊLLO, 2010, p. 127).

Na primeira metade do século XIX, surgiram também as pioneiras considerações sobre as práticas corporais na legislação (MEL0; PERES, 2014b). Um interessante exemplo é o Decreto de 15 de julho de 1837, da Assembleia do Rio de Janeiro, tratando da inserção de novos conteúdos nas escolas, entre os quais a "ginástica e defesa do corpo, compreendidos nado, equitação e dança” (JORNAL DO COMÉRCIO, 17 jul. 1837, p. 1).

Ainda tardaria algumas décadas para que essa medida se efetivasse, mas pode-se fazer referência ao caso do Colégio Pedro II, onde o ensino da ginástica teve início nos anos 1840 com a contratação, como vimos, de Guilherme Luiz de Taube. 0 que por lá houve, a despeito da importância desse estabelecimento, não diferiu substancialmente do que ocorreu em outras escolas.

Que escolas? 0 que houve em outros estabelecimentos educacionais no que tange às práticas corporais? Quais foram os conteúdos e as intencionalidades que cercaram o seu trato? Este artigo objetiva discutir as pioneiras experiências, nos colégios fluminenses, de ensino de práticas corporais, conteúdos que somente iriam lograr maior reconhecimento no último quartel do século XIX, a reboque dos desdobramentos da Guerra do Paraguai (MELO; PERES, 2014b).

Não serão por mim abordados os casos do Colégio Pedro II - já exaustivamente discutido por Cunha Júnior (2008) - e das escolas militares (que vão merecer um estudo próprio). Da mesma forma, não tratarei das experiências com a dança - já investigada em estudo anterior (MEL0, 2016a) -, mas sim das iniciativas com ginástica, esgrima, natação, equitação e jogos, outras modalidades que foram oferecidas pelos estabelecimentos educacionais fluminenses.

Para alcance do objetivo, como fontes foram utilizados periódicos publicados no Rio de Janeiro. Teve-se em conta que, no século XIX, a imprensa já assumia o papel de arena pública, repercutindo os posicionamentos sobre as novidades que chegavam ao

11- Em 1817, a esgrima de novo apareceu num comunicado de abertura do ano letivo publicado na Gazeta do Rio de Janeiro (12 fev. 1817, p. 4). Chamada semelhante se observa em 1819 (GAZETA DO RIO DE JANEIRO, 6 mar. 1819, p. 1).

12- Houve precedentes de preocupação com a prática no Portugal do século XVIII, no Colégio Real de Nobres da Corte e Cidade de Lisboa (SANCHES, 2003). 
país. Para trato do material, tive em conta as sugestões de Luca (2005). No que tange às imagens (litografias e matérias jornalísticas), optou-se por um uso ilustrativo.

0 recorte temporal adotado considerou a primeira vez em que apareceu nos jornais uma escola oferecendo a ginástica (Colégio Emulação, em 1836) e o período em que começou a se tornar mais usual a oferta de práticas corporais nos estabelecimentos educacionais (década de 1850), num cenário em que melhor se estabilizou a burocracia estatal - inclusive as iniciativas de estruturação do sistema escolar -, outro momento em que o Brasil e a sociedade fluminense passaram por grandes mudanças nos mais diversos âmbitos (MEL0; PERES, 2014b).

Deve-se ter em conta que, em 1853, anunciou-se que "separou-se do curso literário e cientifico tudo o que com ele não tinha referência, e que só faz parte da educação física, ou constitui uma prenda na sociedade" (BRASIL, 1853, p. 65). Já a Reforma Couto Ferraz (BRASIL, 1854), que estabeleceu normas para o ensino primário e secundário na Corte, ratificou distinções de status entre os docentes, manifestas até mesmo no salário diferenciado, os de dança, desenho, música e ginástica recebendo menos. Isto é, se, naquele período, as práticas corporais tornaram-se mais reconhecidas como conteúdos escolares, também houve mais denotadamente um processo de hierarquização das cadeiras, algo que impactou a disciplina Educação Física no decorrer do tempo.

Com limites em razão das características das fontes utilizadas, este artigo consiste em um estudo da cultura escolar, entendida nos termos inferidos por Julia (2001, p. 10): "conjunto de normas que definem conhecimentos a ensinar e condutas a inculcar, e um conjunto de práticas que permitem a transmissão desses conhecimentos e a incorporação desses comportamentos". Como sugere o autor:

Convém examinar atentamente a evolução das disciplinas escolares, levando em conta diversos elementos que, em ordem de importância variada, compõem essa estranha alquimia: os conteúdos ensinados, os exercícios, as práticas de motivação e de estimulação dos alunos, que fazem parte destas "inovações" que não são vistas, as provas de natureza quantitativa que asseguram o controle das aquisições. (JULIA, 2001, p. 34).

Discuto a inserção de práticas corporais no momento em que a forma escolar (VINCENT; LAHIRE; THIN, 2001) estava se estabelecendo no Brasil (FARIA FILHO; VIDAL, 2000). Trata-se, portanto, de uma investigação sobre como um assunto foi se tornando relevante no cotidiano escolar e se estabelecendo como uma disciplina propriamente dita. ${ }^{13}$ Isto é, como foi se definindo um conjunto de conteúdos que se estruturou nos estabelecimentos educacionais tendo em conta objetivos que precisam ser pelo pesquisador identificados. Isso se deu porque emergiram certas exigências e necessidades sociais. Como sugere Viñao (2008, p. 203), "este esforço de transmutação didática que implica a escolarização e academização de um saber, (é) em geral originado fora do ambiente escolar".

Tive em conta que a escola não era o único fórum no qual as práticas corporais eram ensinadas, havendo, em diversos graus, contatos com o que ocorria no âmbito do entretenimento e em outros espaços não escolares. Essas iniciativas se relacionavam a algo

13- Sobre a noção de disciplina escolar, cf. Chervel, 1990. 
que se instituía naquela primeira metade do século XIX: o aumento da exposição do corpo na nova dinâmica social, o que desencadeou intervenções de controle e disciplinarização (VIGARELLO; HOLT, 2008).

Ao considerar essa multiplicidade de espaços, procurei estar atento ao que sugere Chervel (1990) em relação à importância de distinguir as finalidades reais e as finalidades do objetivo. Para o autor, deve-se

[...] tomar consciência de que uma estipulação oficial, num decreto ou numa circular, visa mais frequentemente, mesmo se ela é expressada em termos positivos, corrigir um estado de coisas, modificar ou suprimir certas práticas, do que sancionar oficialmente uma realidade. (CHERVEL, 1990, p. 190).

Assim sendo, lançar um olhar para os primórdios das preocupações com as práticas corporais em cenários escolares não é somente refletir sobre esses fenômenos, bem como sobre as pioneiras experiências dos estabelecimentos educacionais, mas também sobre uma faceta da sociedade fluminense naquele contexto de profundas transformações: a articulação de diferentes formas de pensar e entabular intervenções sociais. Como bem lembra Chervel (1990, p. 220), as "disciplinas escolares intervêm igualmente na história cultural da sociedade. Seu aspecto funcional é o de preparar a aculturação dos alunos em conformidade com certas finalidades".

Vale um último comentário nesse já longo introito. Ainda que existam outros estudos sobre a educação física no Brasil do século XIX, alguns deles citados no decorrer deste artigo, praticamente nenhum se debruça sobre a primeira metade da centúria. Até mesmo por isso, antes desenvolvi outros estudos em que procurei ampliar o olhar sobre esse período, no que tange à legislação (MEL0; PERES, 2014b), ao olhar dos médicos (MELO; PERES, 2014a), a outras manifestações sociais das práticas corporais (MEL0; PERES, 2014a; MELO, 2016b; MELO, 2016a).

\section{Pioneiras iniciativas}

A primeira referência ao ensino da ginástica em uma escola fluminense foi encontrada, em 1836, num anúncio do Colégio Emulação (JORNAL DO COMÉRCIO, 23 set. 1836, p. 4), estabelecimento exclusivo para meninos, que se apresentava como cumpridor, desde as primeiras letras, das exigências para os que desejassem cursar Direito ou Medicina. Eram oferecidas aulas de dança e, de forma gratuita, "os exercícios ginásticos e a arte de nadar" (DIÁRIO DO RIO DE JANEIRO, 8 mar. 1837, p. 3).

0 perfil do colégio ajuda-nos a entender esse pioneirismo na introdução do ensino de práticas corporais. 0 seu diretor e proprietário - o português José Soares de Azevedo - destacou-se por suas ideias avançadas, vinculando a educação ao progresso do país (BLAKE, 1883). Polêmico, ligado à maçonaria, formado em história e filosofia na França, teve posteriormente uma notável carreira docente em Recife, onde foi proprietário do Colégio Pernambucano e professor no Liceu e no Ginásio Provincial. ${ }^{14}$

14- Para mais informações, cf. <http://www.iahgp.com.br/historico/fund.php>. Acesso em: 23 jan. 2017. 
Mesmo com curta duração, o Emulação marcou seu tempo, inclusive por inovações como um curso de filosofia, retórica e poética oferecido por Gonçalves Magalhães, um dos introdutores do Romantismo no Brasil, futuro docente do Colégio Pedro II (RIOS FILHO, 2000). ${ }^{15}$ Era um colégio para membros da elite, ainda que oferecesse bolsas para jovens pobres indicados pela Sociedade Amante da Instrução. Foi reconhecida como uma das primeiras escolas mais bem estruturadas da Corte, influenciando suas congêneres.

Figura 4 - Anúncio do Colégio Emulação

O COLLEGIO EMUL\Ç̄̃o, rua detraz do Hospicio n. 266, de que be Director José Soares d'Azevedo, encerra em seu plano, franco ao publico a qualquer hora, todos os preparatorios que a lei exige para os Cursos de Direito e de lle dicina, desde Primeiras Letras. Os professores das diversas aulas sāo de huma reputação conhecida ; e o edificio he muito vasto, com jardim e agua para recreio dos pensionistas e externos. Ha de mais hum curso de gymnastica e nataçāo, gratuito para todos 08 alumnos.

Fonte: Jornal do Comércio 24 abr. 1837, p. 4.

0 colégio se orgulhava de suas instalações, "o edifício muito vasto e um formoso jardim para recreio dos pensionistas e alunos externos” (DIÁRIO DO RIO DE JANEIRO, 8 mar. 1837, p. 3), preocupações que se tornariam mais usuais a partir de metade do século XIX, por motivações pedagógicas e exigências de mercado, relacionadas inclusive às exigências de saúde e salubridade (LIMEIRA, 2012).

Era no jardim que, às quintas e aos domingos, ministravam-se os "exercícios de ginástica” (JORNAL DO COMÉRCIO, 23 set. 1836, p. 4). Quanto à natação, não encontramos maiores informações de dia e local. Provavelmente, como se deu com outras escolas, utilizavam-se o litoral, as barcas de banhos instaladas na Baía de Guanabara ou mesmo um tanque de banho (MELO; PERES, 2016a). Nos anúncios, asseverava-se que os professores eram "os mais hábeis desta Corte", sem, contudo, citarem-se seus nomes.

Exaltou o Colégio Emulação uma longa matéria publicada no Correio Oficial periódico que veiculava notícias que interessavam ao governo regencial -, provavelmente da lavra do editor João Cândido de Deus e Silva, conhecido por seu envolvimento com a proclamação de independência. Entre as referências elogiosas, citou-se a oferta de aulas de ginástica:

15- Para uma interessante notícia a esse respeito, cf. Jornal do comércio, 17 jan. 1838, p. 2. 
Há já alguns meses que os alunos se dão em um jardim espaçoso a exercícios ginásticos de uma utilidade geralmente reconhecida, e cujas repetições, sob as vistas de um hábil instituidor, fazem adquirir tal agilidade, tal facilidade de resistir aos trabalhos, tal intrepidez, que parecem incriveis. É um passo a mais que acaba de dar-se no melhoramento de ensino, porque uma educação vigorosa e robusta exerce uma grande influência no caráter dos homens, e depois nos destinos dos povos. (CORREIO OFICIAL, 28 nov. 1836, p. 3).

Já nesse momento começava a se estabelecer, mesmo que de forma não tão explícita como na segunda metade do século XIX, uma oposição entre a ginástica apresentada nos circos e teatros e aquela sugerida a ser ensinada às crianças e jovens. ${ }^{16}$ Assim se posicionou um cronista do Diário do Rio de Janeiro, enfatizando um certo sentido de masculinidade considerado necessário para a construção da nação e a defesa das fronteiras nacionais:

\footnotetext{
A ginástica, porém, nas cidades é absolutamente precisa, não para formar arlequins, como o povo cuida, mas para educar homens vigorosos. Os mimos e branduras com que as pessoas mais ricas e poderosas costumam criar os filhos, os fazem comumente efeminados e de débil compleição. É esta mal dirigida educação física da primeira infância que a arte ginástica depois corrige com o exercício acertado e regular. (DIÁRIO DO RIO DE JANEIRO, 9 mar. 1838, p. 1).
}

0 Colégio Conceição, que se instalou no local onde estava situado o Colégio Emulação, também dedicou atenção à ginástica. 0 perfil desse estabelecimento guardava semelhanças com o anterior.

Figura 5 - Anúncio do Colégio Conceição

\section{COLLEGIO CONCEIÇĀO}

\begin{tabular}{|c|}
\hline 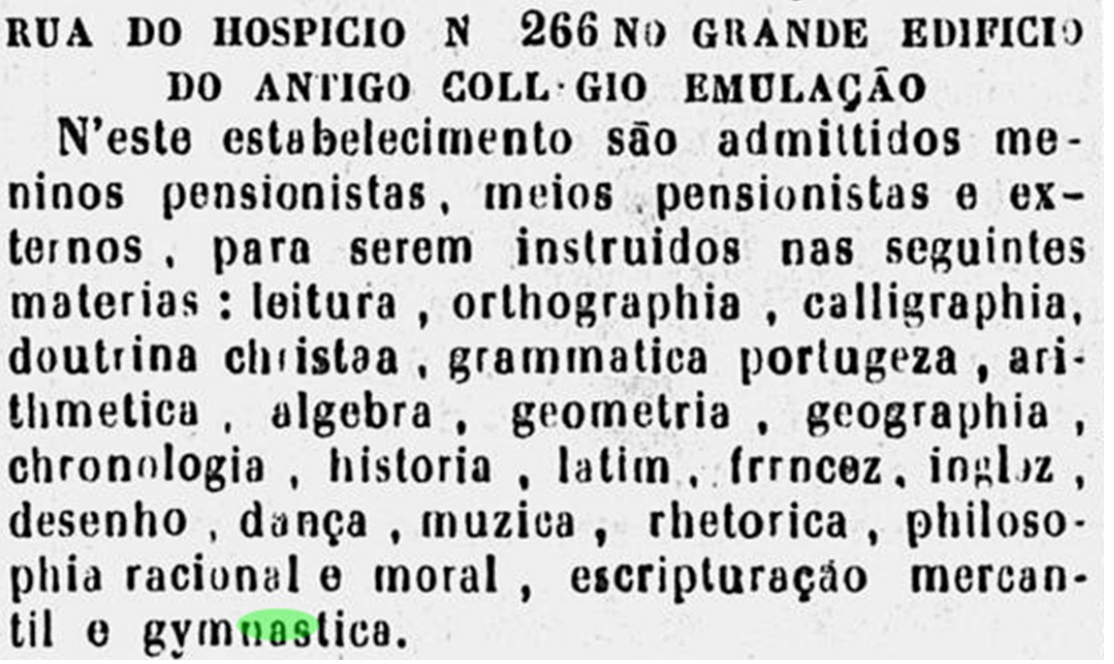 \\
\hline
\end{tabular}

Fonte: Diário do Rio de Janeiro, 5 ago. 1845, p. 4.

16- Para uma abordagem sobre o tema, cf. Herold Junior, 2005 
Não conseguimos, todavia, muitas informações sobre essa escola, bem como sobre o Colégio Educação Literária e Moral. Acerca deste, sabemos um pouco mais sobre o ensino das práticas corporais. Em um de seus anúncios, percebemos que, nos seus estatutos, os conteúdos estavam divididos em cinco classes. Integravam a $5^{\text {a }}$ classe "a ginástica e outros exercícios físicos tendentes a desenvolver o corpo" (0 PHAROL CONSTITUCIONAL, 23 ago. 1844, p. 3), além de grego, alemão e italiano. Dois anos depois, a ginástica e a esgrima integravam a $7^{\text {a }}$ classe, lecionadas por M. Rechau (JORNAL DO COMÉRCIO, 19 mar. 1844, p. 5), sobre o qual não conseguimos mais informações, a não ser que se tratava de um estrangeiro.

Figura 6- Anúncio do Colégio Educação Literária e Moral

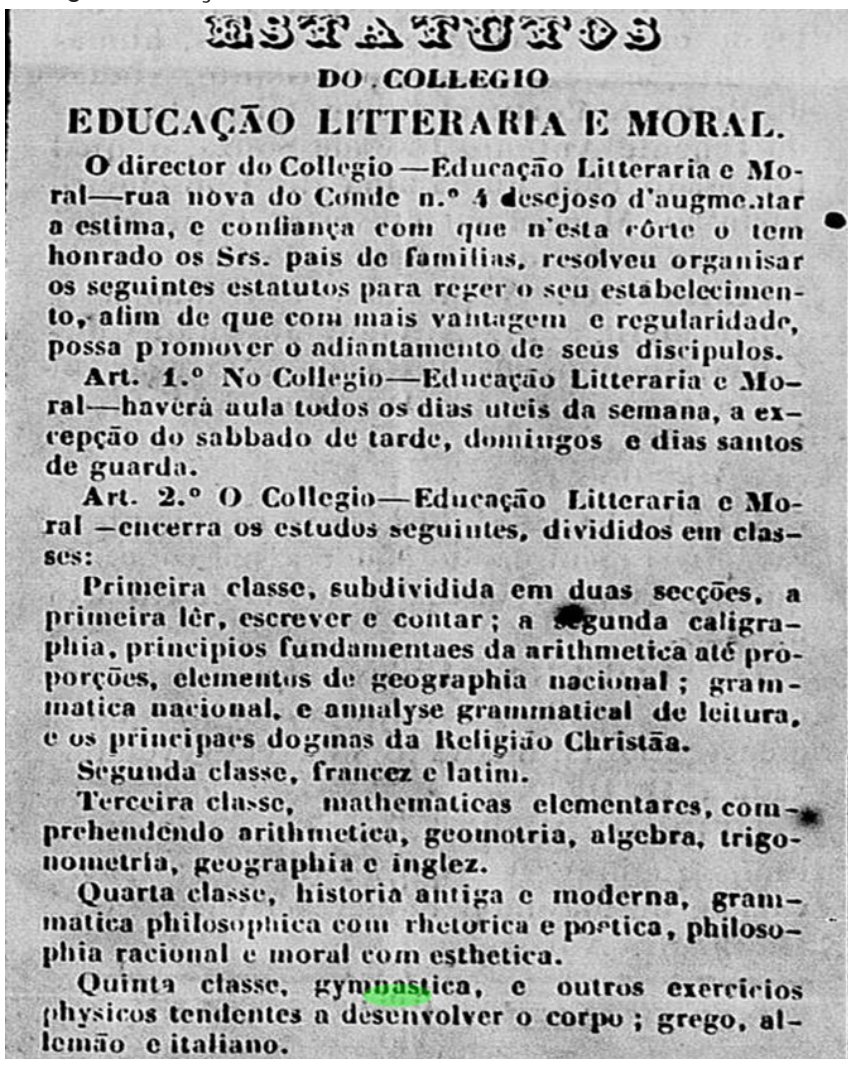

Fonte: 0 Pharol Constitucional, 23 ago. 1844, p. 3.

Aparentemente, isso significa que tais conteúdos eram menos valorizados. 0 colégio inclusive estabelecia que "os estudos de ginástica e outros estudos recreativos tendentes a desenvolver o corpo serão somente exercidos em dias feriados" (O PHAROL CONSTITUCIONAL, 23 ago. 1844, p. 3). De toda forma, trata-se de mais um indicador de que, mesmo embrionariamente, começava a se tornar mais usual a oferta das práticas corporais em cenários escolares. 
Outro que dedicou atenção ao tema foi o Colégio de Botafogo ${ }^{17}$. No seu anúncio publicado no Jornal do Comércio, o diretor, Mr. Hitchings, usou uma longa citação de Almeida Garret - escritor, intelectual e político português seguidor das ideias de Rosseau (AZEVED0, 1966) - para sustentar seu intuito:

Eis aí porque considero os exercícios ginásticos (complemento da educação física) como importantíssima parte da educação em geral, e da qual dependem as duas outras partes (educação moral e intelectual). Em consequência dessa convicção, tenho sempre feito praticar a meus alunos os mesmos exercícios ginásticos com as modificações convenientes a suas idades, compleições, etc. (JORNAL DO COMÉRCIO, 16 set. 1846, p. 3).

Figura 7- Anúncio do Colégio de Botafogo

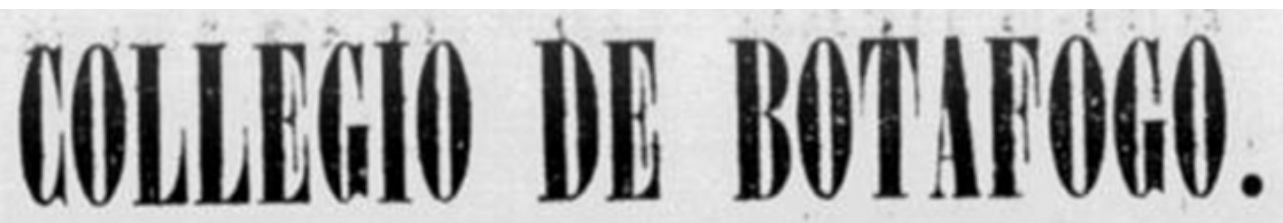

« O fim da educaçāo é fuzer um membro util e feliz da sociedade. O objecto da educaçāo é formar o corpo, o coraçāo e o espirito.

Uim máo corpo, mal formado é doentio, cơm máo estomago e máos nervos, rara e quasi impossivelmente terá um coraçāo bein formado, forte, aberto, generoso. Com máos nervos e máo coraçāo, máo hả de ser o cerebro.

- Nāo esqueça-se, no meio de todos os cuidados do intellectual e moral da educaçāo, que è necessario completar e aperfeiçoar o physico. E' meio desse complemento, e coróa dessa perfeiçâo a gy mnastica. Desde a sinpoles carreira, a luta, a nataçāo, a equilaçāo e esgrima comprehendendo tudo na generalidade da gymnastica.

Fonte: Jornal do Comércio, 16 set. 1846, p. 3.

17- Não se trata do Colégio de Botafogo que fora antes o Colégio de Instrução e Educação de Meninas, aquele que dividiu com o Colégio de Meninas da Baroneza de Geslin, durantes décadas, a primazia na formação educacional feminina na Corte. 
A intencionalidade do diretor era explicitada na propaganda. Ao sintonizar sua proposta com o que havia de mais avançado no cenário internacional, desejava desenvolver nos alunos hábitos elegantes e saudáveis (por meio do desenvolvimento físico), utilizando como estratégias a ginástica, a natação, a esgrima, a luta, a corrida e a equitação.

Um dos professores do Colégio de Botafogo foi o espanhol Frederico Hoppe, que também ensinava esgrima em uma sala particular, na Academia da Marinha, e teve uma turbulenta passagem pelo Pedro II, onde lecionou por dois curtos períodos (CUNHA JÚNIOR, 2008). Vale observar que mesmo o prestigioso colégio sentia a falta de docentes habilitados e capacitados para atuar com as práticas corporais.

Já no "colégio preliminar e científico para o sexo masculino, situado na Rua dos Arcos n. 40" (DIÁRIO DO RIO DE JANEIRO, 17 nov. 1845, p. 4), a ginástica era oferecida apenas para a instrução primária, não para a secundária, nem como curso à parte, como era o caso da dança.

Figura 8 - Anúncio de colégio

\section{PLANO}

dos estudos novamente coordenado do antigo e bem conhecido collegio preliminar e scientifico para o sexo mascolino, situado na rua dos $\operatorname{Arcos} \mathrm{n} .40$.

Instrucçāo primaria. - Leitura, escripta , grammatica, arithmetica theorica e pratica, doutrina christāa, civilidado, exercicios de declamaçāo e gymnastica.

Instrucçāo secundaria. - Lingua latina, franceza, ingleza, allemáa, geographia, historia sagrada, nacional, e universal, algebra o geo. metria.

Bellas arles. - Dezenho, pintura , musica

$\theta$ dança.

O director d'este collegio affiança que as di. versas classes indicadas no plano sâo preen. chidas por habeis professores; e que um re-

Fonte: Diário do Rio de Janeiro, 17 nov. 1845, p. 4. 
Nesse caso, a regularidade é que se tratava de uma oferta para meninos. Para as meninas, não era usual a previsão de ensino de práticas corporais, à exceção das aulas de dança, que eram, em geral, ministradas para ambos os sexos (MELO, 2016b; MELO, 2016c).

A única referência de aulas de ginástica para meninas foi encontrada nos anúncios do Colégio da Estrela (0 AMERICANO, 7 fev. 1849, p. 4). 0 plano de ensino era dividido em duas seções: uma de educação, integrada por conteúdos da doutrina cristã e por trabalhos domésticos; e outra de instrução, integrada por conteúdos de formação geral. Desta fazia parte a ginástica, integrando a $8^{a}$ classe, sob a responsabilidade de Bernardino Queiroz, que tinha também de lecionar música, dança, piano e canto.

Figura 9 - Anúncio de Colégio da Estrela

COLLEGIO DA ESTRELLA PARA MEXINAS ESTABELECIDO Na RUA DA ASSEMBLÉa N." 16 , E DYRIGIDO PEIA SR. ${ }^{a}$ D. MARIA ISABEL DE LEMOOS, EXREGENTE DO COLLKGIO DAS ORPHÃS.

A directora deste estabelecimento tāo util quanto completo, tendo em vista a melhor ordem e mais vantagem no progresso dos estudos, que illustram e aperfeiçoam o espirito do sexo feminino, dividiu o ensino que tem de dar ás suas educandas em duas secçōes. Na primeira, que confiou ao cuidado d'uma inspectora, comprehendeu as materias de educação; e na segunda resumiu todas as de instrucção. Por este tāo sim-

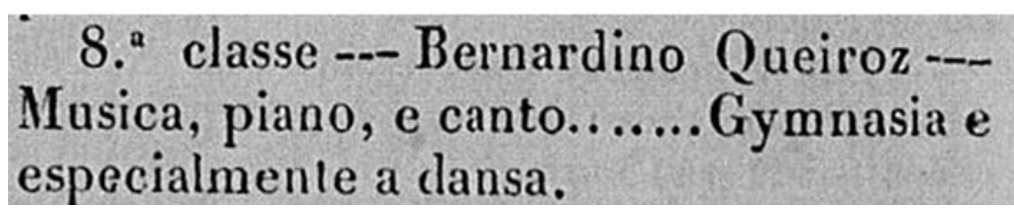

Fonte: O Americano, 7 fev. 1849, p. 4.

0 colégio era dirigido por Maria Isabel de Lemos Vale Caldre e Fião, esposa e parceira de trabalho de José Antônio do Vale Caldre e Fião, jornalista, médico, professor, literato e abolicionista convicto. Ambos cultivavam a ilustração, valorizando tanto a literatura quanto a ciência.

Maria Isabel sempre valorizou uma formação ampla, dando atenção também às aulas das belas artes, para estas se esmerando em construir instalações adequadas 
(0 AMERICANO, 20 abr. 1850, p. 4). Para ela, tais conteúdos contribuiriam para uma educação feminina renovada:

[...] são as aulas que mantém sempre a diretora deste colégio, que, cônscia dos esforços que tem empregado para educar boas mães de família e ilustradas senhoras, o oferece à consideração de todos os senhores, pais e tutores, que desejam dar uma educação às suas filhas e pupilas, digna do adiantamento do século em que vivemos. Ela não se poupará em aumentar o número de suas aulas à proporção da ilustração de suas alunas. (CORREIO MERCANTIL, 21 mar. 1853, p. 4).

Vejamos, contudo, que o docente responsável, Bernardino Queiroz, era musicista, compositor e conhecido professor da arte. Entende-se que as atividades de música e de dança estivessem sob sua responsabilidade. Mas que qualificação (ou mesmo adesão) teria para ministrar a ginástica? É possível que, mesmo anunciados, os exercícios ginásticos não fossem ensinados nas aulas (talvez mesmo por considerar-se que a dança era a ginástica adequada para as meninas).

De toda forma, essa escola estava entre aquelas que, na virada dos anos 1840/1850, passaram a dedicar maior atenção ao ensino das práticas corporais, como veremos no próximo item.

\section{Início da consolidação}

A maior valorização do ensino das práticas corporais em instituições escolares se deu pari passu com a ainda maior estruturação do mercado de entretenimentos (onde a ginástica seguiu ocupando espaço de destaque), bem como com o aumento da influência dos posicionamentos de médicos sobre os exercícios físicos. Um exemplo é o Colégio de Petrópolis, exclusivo para meninos, que oferecia aulas de ginástica, esgrima e dança.

0 perfil desse estabelecimento fica claro na sua apresentação pelos jornais. Destaca-se a preocupação com o "desenvolvimento físico da mocidade estudiosa", segundo seu diretor, "uma exigência indispensável do progresso científico” (CORREIO MERCANTIL, 12 set. 1849, p. 4).

Figura 10 - Anúncio do Colégio de Petrópolis

\section{COLHCHO DR PETROPOLIS.}

Principiarão com a entrada do anno de 1850

os exercicios deste estabelecimento.

As materias de ensino, incluindo as primeiras letris, são.as seguintes :

- Religião catholica, e mural christã.

Calligraphia-arithmetica-grammatica.

Gengraphia-listoria universal-astronomia.

As linguas, latina, ingleza, franceza, allemãa.

Desenbo-geometria-zoologia-mineralogia.

Physica, e chimica elementar-mechanira.

As mathematicas-em todas as suas subdivisões.

Philosophia-rhetorica-poetica.

Contabilidade, escripturação. e formulario commercial.

Musica-Canto-piano.

Gymnastica-esgrima-dansa.

Fonte: Correio Mercantil, 14 nov. 1849, p. 4 
Até mesmo por isso, os anúncios ressaltavam a adequação das instalações do ponto de vista da higiene e da saúde. Não se tratava da usual adaptação de espaços, mas sim de construir uma boa estrutura do ponto de vista material e simbólico. Tendo em conta as práticas corporais, "para a recreação durante o tempo de chuva fez-se um grande salão ou colunata em que os exercícios ginásticos terão lugar". ${ }^{18}$

Figura 11 - Colégio de Petrópolis

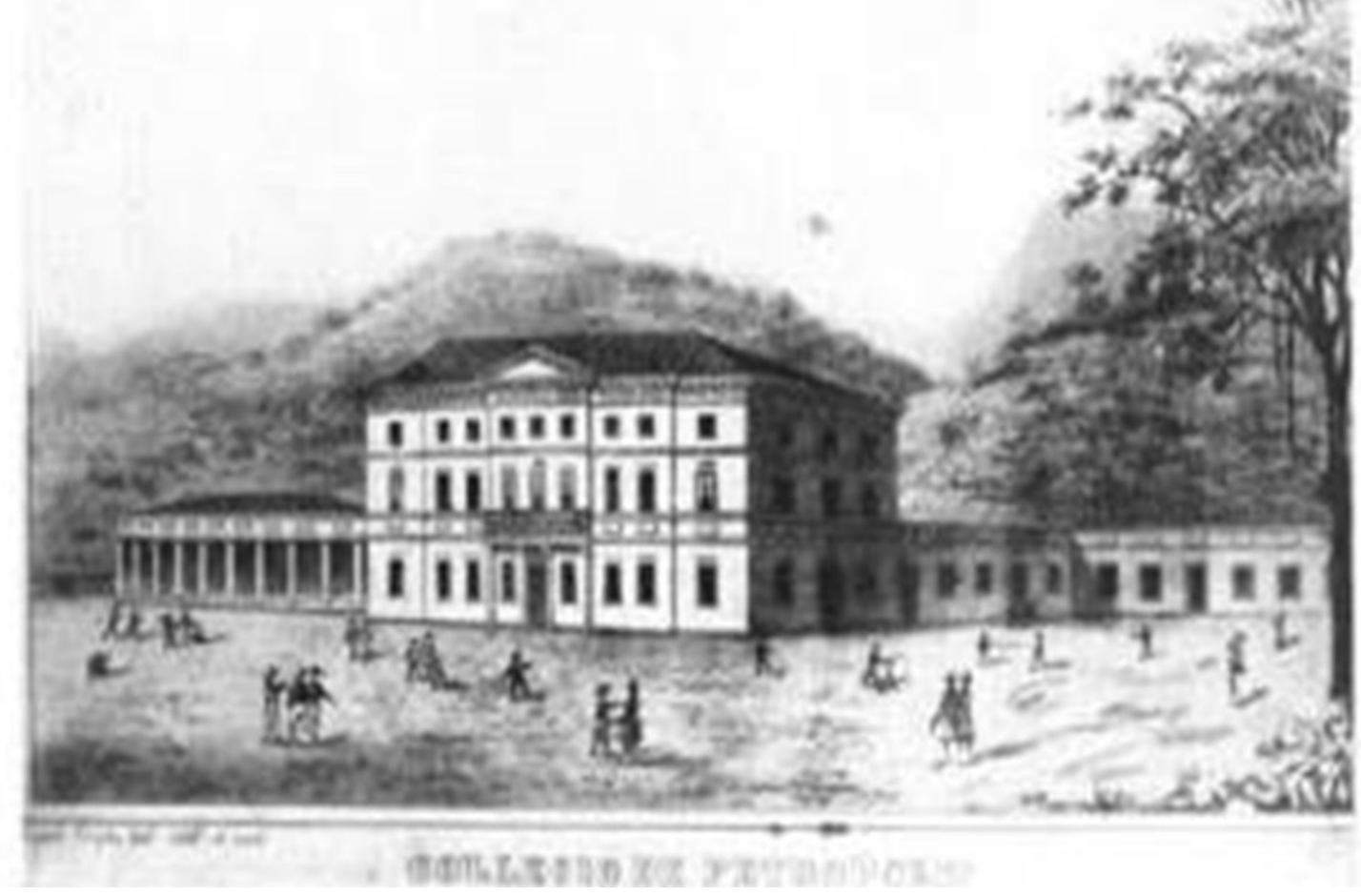

Fonte: Litografia de Heaton e Rensburg.

O Colégio de Petrópolis foi fundado em 1848 pelos portugueses de origem germânica Henrique Kopke e Guilherme Kopke. Tratava-se de uma iniciativa claramente destinada à formação da elite nacional, inspirada em modelos europeus de ensino, uma experiência que logrou grande repercussão e reconhecimento no seu tempo, inclusive por parte da família imperial.

18- Panizzolo (2006) informa que esse salão possuía $450 \mathrm{~m}^{2}$. 
Figura 12 - Rua Nassau e o Colégio de Petrópolis



Fonte: Fotografia de Pedro Hees (circa 1860-1870). Coleção Thereza Christina Maria/Biblioteca Nacional.

Como sugere Panizzolo (2006, p. 63), "o Colégio da família Kopke de fato constituiu-se como um estabelecimento de ensino modelar, tanto no que se refere aos elementos arquitetônicos de sua criação e instalação quanto ao que diz respeito à estrutura pedagógica". 0 seu reconhecimento como instituição padrão, que contribuía para o desenvolvimento intelectual e físico de seus alunos, chegou a ser positivamente ironizado em Semana Ilustrada.

Figura 13 - Charge sobre o Colégio Kopke

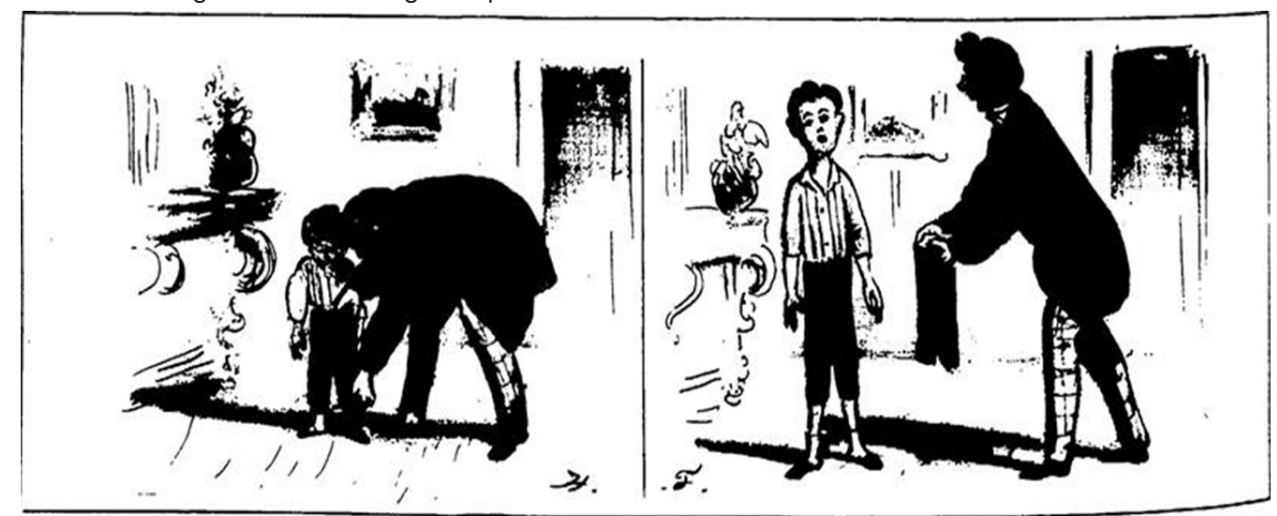

Inconveniente de mandar educar os filhos mo collegio Kopkt: Petriopolis é tão saudarel que a calça feile ia segunda-feira já está curta no sabbado.

Fonte: Semana Ilustrada, 30 mar. 1862, p. 4. 
Perfil semelhante tinha o Instituto Colegial de Nova Friburgo, fundado em 1841 pelo britânico naturalizado João Henrique Freese. Nessa escola, organizada a partir de inovações europeias, também se dedicava grande atenção às práticas corporais. A inspiração das aulas era o modelo inglês, tendo sido uma das primeiras que assumidamente inseriu jogos atléticos entre os conteúdos, especialmente o críquete e as corridas.

Figura 14 - Vista dos fundos do Instituto de Nova Friburgo

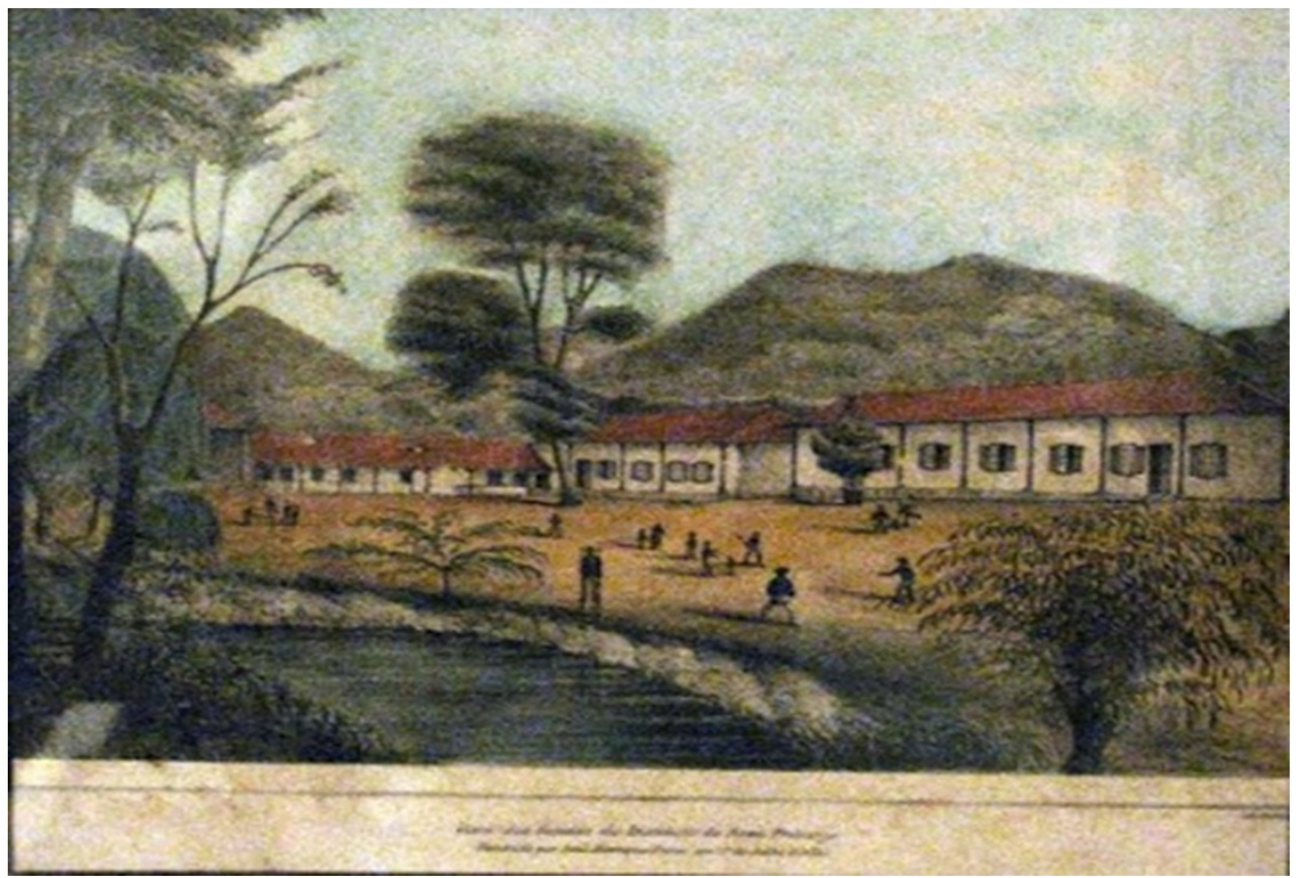

Fonte: Litografia da Oficina Ludwig \& Briggs, 1843.

0 tema foi tratado nos estatutos do colégio (assumidamente inspirados nos do Colégio de Petrópolis). 0 capítulo III é integralmente dedicado à educação física, introduzido pela divisa do poeta romano Juvenal, "Mens sana in corpore sano" (JORNAL DO COMÉRCIO, 28 mai. 1854, p. 6). 0 intuito anunciado era "dar aos alunos uma constituição forte e corpo robusto, desenvolvendo as suas forças físicas”, por meio de hábitos de higiene (inclusive banhos), boa alimentação e exercícios adequados: natação, ginástica, esgrima, jogos atléticos, dança. ${ }^{19}$ As aulas eram realizadas todas as manhãs, entre 6 h30 e 7 h45.

A valorização das práticas corporais era também notável pelo lugar que ocupavam nas cerimônias festivas de fim de ano. Em 1856, demonstrações de esgrima e ginástica encerraram a semana de exames de todas as cadeiras, ocasião em que se distribuíram as medalhas e condecorações para os melhores alunos (CORREIO MERCANTIL, 15 mai. 1856, p. 2). No decorrer do tempo, essa foi uma ocorrência usual. ${ }^{20}$

19- Dança e esgrima integravam o curso regular, enquanto a ginástica, a natação e os jogos eram pagos à parte.

20- Sobre o tema, cf. também Melo; Peres ( 2016b). 
Seguiam as dificuldades para conseguir professores apropriados para lecionar as práticas corporais. No caso do Instituto Colegial, em certa ocasião, Freese informou que contratou um oficial de engenharia alemão, que encerrara sua prestação de serviços ao Exército brasileiro, para atuar com a "esgrima, o jogo da espada e outros exercícios militares e ginásticos” (DIÁRIO DO RIO DE JANEIRO, 19 jun. 1855, p. 3). Tratava-se de Guilherme Frederico Augusto Lachmund.

Também guarda algumas semelhanças com as experiências anteriores a presença das práticas corporais no cotidiano do Colégio de São Pedro de Alcântara, um dos mais importantes da capital. Dirigido pelo cônego José Mendes de Paiva e por três de seus irmãos padres, contava com uma comissão de inspeção integrada por personalidades do Império (como o Marquês de Abrantes, o Marquês de Caxias e o Conselheiro Eusébio de Queiroz). 0 já citado Frederico Hoppe era o docente de esgrima e exercícios ginásticos (JORNAL DO COMÉRCIO, 16 out. 1846, p. 4).

Como boa parte dos outros colégios citados, um dos pontos fortes do São Pedro de Alcântara, algo exaltado nos seus anúncios, era o conforto e a adequação - do ponto de vista da higiene e da saúde - de suas instalações localizadas no, à época ainda bucólico, bairro do Rio Comprido (LIMEIRA, 2012). ${ }^{21}$ Mereciam semelhante atenção os equipamentos para as aulas de práticas corporais, no entender da direção "indispensáveis para o desenvolvimento físico e moral dos alunos” (ALMANAK LAEMMERT, 1857, p. 435).

Figura 15 - Colégio de São Pedro de Alcântara



Fonte: Litografia de Pedro Godofredo Bertichen, 1856.

Vale salientar que, em 1851, em uma inspeção dirigida por Justiniano José da Rocha, foi destacado, entre tantos elogios, o "pátio do recreio, que estava coberto de areia

21- Para mais informações sobre o Colégio, cf. também Conceição (2012). 
grossa e munido de instrumentos para exercícios ginásticos" (CORREIO MERCANTIL, 18 dez. 1851, p. 2). Para o ensino da natação, o colégio oferecia "um grande tanque [...], onde os alunos aprendem a nadar, de forma oval, com 96 palmos de comprido, 46 de largo e 7 de fundo na parte inferior e 5 na parte superior" (ALMANAK LAEMMERT, 1857, p. 435).

A valorização das práticas corporais era ainda mais explícita no Liceu Roosmalen, dirigido pelo francês A. Roosmalen, estabelecimento que tinha dois intuitos claramente anunciados: sintonizar-se com os avanços e as inovações educacionais mundiais e, até mesmo por isso, como as escolas anteriores, apresentar uma estrutura escolar adequada ao que se esperava de padrões civilizados de higiene e saúde (LIMEIRA, 2008).

Em dezembro de 1853, quando seus alunos foram submetidos a uma primeira avaliação pública, presidida pelo Visconde de Abrantes, o diretor destacou: "Não excluiremos pois do nosso liceu nenhuma ciência, nenhuma arte, nenhuma espécie de instrução" (CORREIO MERCANTIL, 25 dez. 1853, p. 2). A busca de uma formação ampla e, ao mesmo tempo, aplicada ajuda a entender o cuidado com as práticas corporais.

Em mais de uma ocasião, o diretor defendeu a importância desses conteúdos. Ressaltava a sua intencionalidade de educar da mesma forma as habilidades intelectuais e do corpo, por isso não tendo "aberto uma casa da educação em limites estreitos e sobretudo sem a possibilidade de ter um ginásio" (CORREIO MERCANTIL, 15 mar. 1858, p. 2). Citando Platão e a influência que os métodos franceses tinham em suas concepções, enumerou o que buscava desenvolver com o ensino das práticas corporais: "a força, a coragem, a agilidade e a destreza".

Em certa ocasião, afırmou: "Dissemos que era nosso fim fazer dos nossos discípulos homens fortes de corpo e de espírito: com esse intento incluímos no nosso método os exercícios de corpo combinados em justa proporção com os exercícios de inteligência" (CORREIO MERCANTIL, 5 ago. 1853, p. 2). Por isso, conclamava os pais a entenderem essa intencionalidade inclusive no que tange à questão das vestimentas. Chamava a atenção para o fato de que "as roupas finas e brancas, o calçado pouco forte não pode durar muito com os jogos e divertimentos que permitimos aos meninos" (CORREIO MERCANTIL, 5 ago. 1853 , p. 2). Para ele, "os trabalhos de jardim, as corridas e os exercícios ginásticos exigem um vestuário de linho forte e sapatos grossos”.

A elegância deveria ceder lugar à eficiência. Ou melhor, a eficiência requisitava um novo padrão de elegância. Os pais deveriam entender que se havia exigências sérias no que tange aos conteúdos "intelectuais", a direção também desejava que "o corpo, que os membros presos nas horas de estudo, se exercitem, se desenvolvam, e se tornem flexíveis nas horas de recreação; disso depende a saúde e a força” (CORREIO MERCANTIL, 5 ago. 1853, p. 2).

A dança, a ginástica, o tiro ao alvo, a equitação e a esgrima - geralmente chamadas de artes do entretenimento, o que denotava a preocupação com essa esfera social - eram cursos pagos à parte, enquanto a natação integrava o conjunto de conteúdos obrigatórios (ALMANAK LAEMMERT, 1855, p. 378). 0 diretor comumente destacava o ensino dessa modalidade, apresentada como "parte dos exercícios indispensáveis" (CORREIO MERCANTIL, 18 dez. 1854, p. 2) em um país que tem que lidar "contra os perigos do mar". Orgulhava-se de dizer que "Quase todos os nossos meninos conhecem os princípios elementares da natação” (REVISTA POPULAR, 1859, p. 2). 
Figura 16 - Anúncio do Liceu Roosmalen

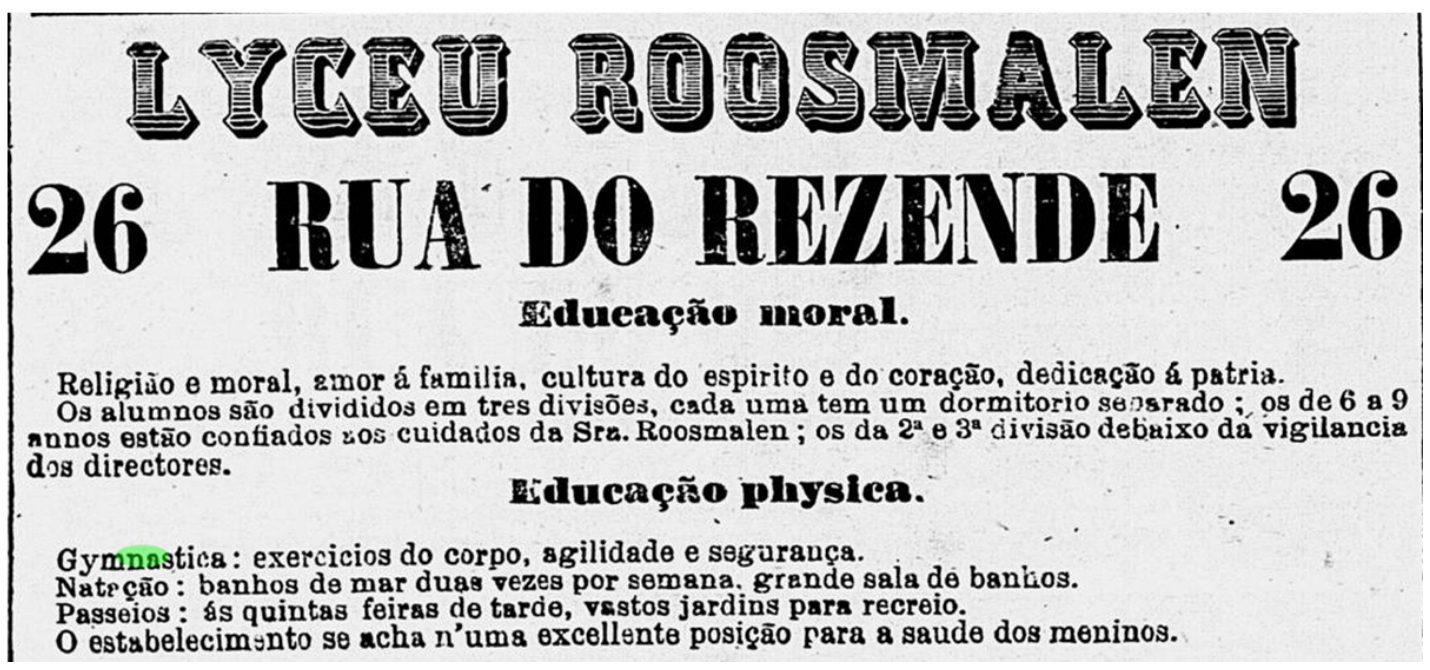

Fonte: Correio Mercantil, 26 e 27 mar. 1859, p. 4.

Reconhecia também a relevância da ginástica, a "arte que dá destreza e vigor a todos os membros" (REVISTA POPULAR, 1859, p. 2), para cujas aulas havia boas instalações, um grande espaço que facilitava o envolvimento dos alunos com "os jogos, as carreiras e todos os exercícios ginásticos tão favoráveis ao desenvolvimento físico e que tanto concorrem para o aperfeiçoamento das partes do corpo mal conformadas”. Destacava o diretor que na França e em outros países europeus era largamente reconhecida a importância dessas práticas. Como observaram Melo e Peres (2016a, p. 294):

\footnotetext{
Em mais de uma oportunidade, Roosmalen deixou claro que as atividades físicas não eram um mero acessório, mas sim integravam a proposta diferenciada de seu liceu, inspirada em uma experiência francesa, "os imensos resultados do coronel Amoros" (CORREIO MERCANTIL, 3 jan. 1857, p. 2). 0 responsável pelo ensino das práticas corporais, aliás, era "Mr. Roosmalen Filho", que, segundo um anúncio, tratava-se de "um dos melhores discípulos do célebre Amoros, exdiretor de todos os ginásios da França” (ALMANAK LAEMMERT, 1857, p. 435).
}

Além dessas escolas citadas, nos jornais apareceram, de forma menos pronunciada, o nome de outras que ofereciam aulas de práticas corporais. No Liceu Tintori, de Niterói, ensinavam-se a dança, a esgrima e a ginástica - integrando o grupo das belas-artes -, nas horas vagas, uma vez por semana, à escolha dos pais, não integrando o grupo dos conteúdos obrigatórios (CORREIO MERCANTIL, 6 jan. 1854, p. 3). Semelhante era o modo de oferta no Novo Colégio de Resende (CORREIO DA TARDE, 18 abr. 1856, p. 4). Também há uma citação ao Colégio Calógeras de Petrópolis (CORREIO MERCANTIL, 31 jan. 1857, p. 2). No Colégio de Santa Cruz (JORNAL DO COMÉRCIO, 9 jan. 1852, p. 4) eram docentes os prestigiados Bernardo Bidegorry - francês, foi um dos mais reconhecidos mestres de ginástica dos anos 1850 (MELO; PERES, 2014a) - e Antonio Francisco da Gama - mestre 
no Pedro II e em outros colégios da Corte, bem como em vários clubes (MEL0; PERES, 2014a), primeiro brasileiro de nascença que identificamos a lecionar práticas corporais.

Anteriormente, houve informações sobre a presença da ginástica no Colégio de Instrução Primária da Rua do Rezende (JORNAL DO COMÉRCIO, 31 dez. 1845, p. 4), no Antigo Colégio Científico (JORNAL DO COMÉRCIO, 22 nov. 1845, p. 3) e no Novo Colégio da Rua do Senado (JORNAL DO COMÉRCIO, 23 abr. 1845, p. 4).

Enfım, ainda que não fosse oferecido na maioria dos colégios, a partir da década de 1830 houve algumas importantes iniciativas de inclusão do ensino das práticas corporais em cenários escolares. Tais iniciativas tornaram-se mais notáveis e explicitadas nos anos 1850, indicando o início de uma consolidação que se daria a partir da década de 1870 .

\section{Conclusão}

As escolas fluminenses que pioneiramente introduziram o ensino de práticas corporais tinham algumas características em comum: procuravam se apresentar como avançadas e em sintonia com as novidades do continente europeu, no qual já mais usualmente se tinha em conta a importância da educação physica; a maior parte era dirigida por estrangeiros; tinham como uma das preocupações notáveis a oferta de boa estrutura escolar, destacando inclusive as instalações para os exercícios físicos.

Pode-se assim resumir os intuitos da oferta de práticas corporais naquelas escolas: auxílio no processo de disciplinarização; contribuição para "todas as necessidades higiênicas exigidas para a boa saúde dos alunos” (CORREIO MERCANTIL, 23 out. 1858, p. 2); garantia de formação ampla do educando, tendo em vista sua performance social (o forjar de uma elite nacional).

Tinham-se em conta as necessidades de consolidação da nação, inclusive no que tange à defesa das fronteiras. Até por isso, em razão das compreensões sobre os papéis sociais a serem assumidos por homens e mulheres, ao contrário da dança, ensinada para ambos os sexos, as outras práticas corporais eram, em geral, ofertadas apenas para meninos, consideradas como contributos para forjar uma certa concepção de masculinidade.

Uma das dificuldades encontradas pelas escolas era conseguir professores capacitados a lecionar de maneira adequada o conteúdo. Majoritariamente, recorreu-se a estrangeiros no Brasil estabelecidos, docentes que tinham algum grau de relação com o tema, adquirido em seus países de origem. Em alguns casos, eram propostas europeias que embasavam sua atuação. Mas deve-se ter em conta que os professores trabalhavam nas mais diferentes esferas. Não raras vezes tinham também inserção nos espetáculos e iniciativas não escolares. A despeito dos discursos diferenciados, é possível que sequer sua atuação fosse tão distinta em cada um desses âmbitos.

De toda forma, deve-se ter em conta algum grau de influência das ideias na época discutidas pelas sociedades de medicina. Na primeira metade do século XIX, entre os facultativos foram crescendo as preocupações com a educação física, tornando-se mais usuais a reflexão e a proposição de que as práticas corporais poderiam ser úteis para a 
educação da mocidade, tendo em vista o progresso da nação. Mesmo sem grande precisão, pode-se dizer que se tratava de um projeto de regularização dos usos do corpo.

Na segunda metade do século XIX, não só aumentaram as iniciativas médicas, como também o número de experiências escolares, observando-se uma maior articulação entre essas esferas, ainda que mais no âmbito dos discursos. No cotidiano das aulas, mesmo sendo criticada pelos que preconizavam um certo uso correto das práticas corporais, a referência de circos e teatros, durante anos, seguiu sendo forte por motivos diversos (como falta de consistência conceitual, carência de corpo profissional e mesmo a força do campo do entretenimento). ${ }^{22}$

Pode-se sugerir que essas experiências pioneiras já se constituíam claramente como propostas de educação do corpo, compreensíveis a partir das três dimensões sugeridas por Vigarello (2003): aquilo que diz respeito a um modelo adequado de uso do corpo (educação do físico e seu princípio da eficácia); o que tange a determinados comportamentos públicos desejáveis (educação do espírito e seu princípio da propriedade); o tocante à inserção do indivíduo, de forma segura, na consolidação de coletivos (princípio da identidade).

\section{Referências}

ALGRANTI, Leila Mezan. Tabernas e botequins: cotidiano e sociabilidades no Rio de Janeiro (1808-1821). Acervo, Rio de Janeiro, v. 24, n. 2, p. 25-42, jul./dez. 2011.

ALMANAK LAEMMERT. Rio de Janeiro: Tipografia Universal, 1855.

ALMANAK LAEMMERT. Rio de Janeiro: Tipografia Universal, 1857.

ALVES, Cláudia Maria Costa. Cultura e política no século XIX: 0 exército como campo de constituição de sujeitos políticos no Império. Bragança Paulista: Edusf, 2002.

AVELAR, Lucas Endrigo Brunozi. A moderação em excesso: estudo sobre a história das bebidas na sociedade colonial. 2010. Dissertação (Mestrado em História) - Universidade de São Paulo, São Paulo, 2010.

AZEVED0, Rafael Ávila de. A influência das ideias pedagógicas de Rousseau em Portugal. Revista da Faculdade de Letras do Porto, Porto, v. 1, p. 281-292, 1966.

BLAKE, Augusto Victorino Alves Sacramento. Dicionário bibliográfico brasileiro. Rio de Janeiro: Tipografia Nacional, 1883.

BRASIL. Ministério do Império. Relatório do ano de 1853: apresentado a Assembléia Geral Legislativa na $2^{\mathrm{a}}$ sessão da $9^{a}$ legislatura pelo Ministro Luiz Pedreira do Couto Ferraz. 1853. Disponível em: <http://brazil. crl.edu/bsd/bsd/u1725/>. Acesso em: 25 jan. 2007.

BRASIL. Decreto $\mathrm{n}^{\mathbf{0}} \mathbf{1 . 3 3 1}$, de 17 de fevereiro de 1854. Aprova o regulamento para a reforma do ensino primário e secundário do município da Corte. 1854. Disponível em: < http://www2.camara.gov.br/legin/fed/

22- Melo e Peres (2014a) tratam disso no que tange ao quartel final do século XIX. 
decret/1824-1899/decreto-1331-a-17-fevereiro-1854-590146-publicacaooriginal-115292-pe.html>. Acesso em: 25 jan. 2007.

CHERVEL, André. História das disciplinas escolares: reflexões sobre um campo de pesquisa. Teoria \& Educação, Porto Alegre, n. 2, p. 177-229, 1990.

CONCEIÇÃO, Joaquim Tavares da. Internar para educar: colégios-internatos no Brasil (1840-1950). 2012. Tese (Doutorado em História) - Universidade Federal da Bahia, Salvador, 2012.

CORREIO MERCANTIL, Rio de Janeiro, 27 jul. 1832.

CORREIO OFICIAL, Rio de Janeiro, 28 nov. 1836.

CORREIO MERCANTIL, Rio de Janeiro, 12 set. 1849.

CORREIO MERCANTIL, Rio de Janeiro, 14 nov. 1849.

CORREIO MERCANTIL, Rio de Janeiro, 18 dez. 1851.

CORREIO MERCANTIL, Rio de Janeiro, 21 mar. 1853.

CORREIO MERCANTIL, Rio de Janeiro, 5 ago. 1853.

CORREIO MERCANTIL, Rio de Janeiro, 25 dez. 1853.

CORREIO MERCANTIL, Rio de Janeiro, 6 jan. 1854.

CORREIO DA TARDE, Rio de Janeiro, 18 abr. 1856.

CORREIO MERCANTIL, Rio de Janeiro, 15 mai. 1856.

CORREIO MERCANTIL, Rio de Janeiro, 31 jan. 1857.

CORREIO MERCANTIL, Rio de Janeiro, 15 mar. 1858.

CORREIO MERCANTIL, Rio de Janeiro, 23 out. 1858.

CORREIO MERCANTIL, Rio de Janeiro, 26 e 27 mar. 1859.

CUNHA JUNIOR, Carlos Fernando Ferreira da. Imperial Collegio de Pedro II: 0 ensino secundário da boa sociedade brasileira. Rio de Janeiro: Apicuri, 2008.

DE-SIMONI, Luiz Vicente. Relatório sobre uma memória do Sr. Guilherme Luiz Taube acerca dos efeitos

físicos e morais dos exercícios ginásticos. Rio de Janeiro: Typ. Imp. e Const. de Seignot-Plancher, 1832. Lido na Sociedade de Medicina do Rio de Janeiro, em 4 de agosto de 1832.

DIÁRIO DO RIO DE JANEIRO, Rio de Janeiro, 8 mar. 1837.

DIÁRIO DO RIO DE JANEIRO, Rio de Janeiro, 9 mar. 1838.

DIÁRIO DO RIO DE JANEIRO, Rio de Janeiro, 5 ago. 1845.

DIÁRIO DO RIO DE JANEIRO, Rio de Janeiro, 17 nov. 1845. 
DIÁRIO DO RIO DE JANEIRO, Rio de Janeiro, 19 jun. 1855.

FARIA FILHO, Luciano Mendes de, VIDAL, Diana Gonçalves. Os tempos e os espaços escolares no processo de institucionalização da escola primária no Brasil. Revista Brasileira de Educação, Rio de Janeiro, n. 14, p. 19-34, ago. 2000.

GAZETA DE NOTÍCIAS, Rio de Janeiro, 26 e 27 nov. 1876.

GAZETA DO RIO DE JANEIRO, Rio de Janeiro, 12 fev. 1817.

GAZETA DO RIO DE JANEIR0, Rio de Janeiro, 6 mar. 1819.

GOUVÊA, Maria de Fátima Silva. 0 Senado da Câmara e a transferência da família real portuguesa para o Brasil: perspectivas de estudos e um índice temático de fontes do Arquivo Geral da Cidade do Rio de Janeiro, 1786-1822. Rio de Janeiro: Arquivo Geral da Cidade do Rio de Janeiro, 2012.

HEROLD JUNIOR, Carlos. Da instrução à educação do corpo: 0 caráter público da educação física e a luta pela modernização do Brasil no século XIX (1880-1915). Educar em Revista, Curitiba, n. 25, p. 237-255, 2005.

JORNAL DO COMÉRCIO, Rio de Janeiro, 3 abr. 1828.

JORNAL DO COMÉRCIO, Rio de Janeiro, 14 jul. 1829.

JORNAL DO COMÉRCIO, Rio de Janeiro, 9 ago. 1832.

JORNAL DO COMÉRCIO, Rio de Janeiro, 9 out. 1832.

JORNAL DO COMÉRCIO, Rio de Janeiro, 23 set. 1836.

JORNAL DO COMÉRCIO, Rio de Janeiro, 24 abr. 1837.

JORNAL DO COMÉRCIO, Rio de Janeiro, 17 jul. 1837.

JORNAL DO COMÉRCIO, Rio de Janeiro, 9 dez. 1837.

JORNAL DO COMÉRCIO, Rio de Janeiro, 17 jan. 1838.

JORNAL DO COMÉRCIO, Rio de Janeiro, 19 mar. 1844.

JORNAL DO COMÉRCIO, Rio de Janeiro, 23 abr. 1845.

JORNAL DO COMÉRCIO, Rio de Janeiro, 22 nov. 1845.

JORNAL DO COMÉRCIO, Rio de Janeiro, 31 dez. 1845.

JORNAL DO COMÉRCIO, Rio de Janeiro, 16 set. 1846.

JORNAL DO COMÉRCIO, Rio de Janeiro, 16 out. 1846.

JORNAL DO COMÉRCIO, Rio de Janeiro, 9 out. 1849.

JORNAL DO COMÉRCIO, Rio de Janeiro, 9 jan. 1852.

JORNAL DO COMÉRCIO, Rio de Janeiro, 28 mai. 1854. 
JORNAL DO COMÉRCIO, Rio de Janeiro, 22 jul. 1857.

JULIA, Dominique. A cultura escolar como objeto histórico. Revista Brasileira de História da Educação, Campinas, n. 1, p. 9-44, jan./jun. 2001.

LIMEIRA, Aline M. 0 comércio da instrução: práticas educativas e publicidade no século XIX. Linguagem, Educação e Sociedade, Teresina, v. 13, p. 84-102, 2008.

LIMEIRA, Aline M. Arquitetura do saber: espaços físicos de colégios privados na corte imperial. Revista Exitus, Santarém, v. 2, n. 2, p. 117-135, 2012.

LUCA, Tânia Regina de. História dos, nos e por meio dos periódicos. In: PINSKY, Carla Bassanezi (Org.). Fontes históricas. São Paulo: Contexto, 2005. p. 111-153.

MAIA, Emílio Joaquim da Silva. Utilidade e necessidade da ginástica. Revista Médica Fluminense, Rio de Janeiro, n. 10/11, p. 9-17, jan. 1840.

MELO, Victor Andrade de. A dança nas escolas do Rio de Janeiro do século XIX (décadas de 1820-1860). Revista Brasileira de História da Educação, Maringá, v. 16, n. 3[42], p. 303-332, 2016a.

MELO, Victor Andrade de. Experiências de ensino da dança em cenários não escolares no Rio de Janeiro do século XIX (décadas de 1820-1850). Movimento, Porto Alegre, v. 22, n. 2, p. 497-508, abr./jun. 2016 b.

MELO, Victor Andrade de. Mudanças nos padrões de sociabilidade e diversão: 0 jogo da bola no Rio de Janeiro (Séculos XVIII e XIX). História, Franca, v. 35, e. 105, p. 1-23, 2016c.

MELO, Victor Andrade de; PERES, Fabio de Faria. A natação nas escolas do Rio de Janeiro do século XIX (1853-1889). Educação em Revista, Belo Horizonte, v. 32, n. 1, p. 287-306, $2016 a$.

MELO, Victor Andrade de; PERES, Fabio de Faria. A gymnastica no tempo do Império. Rio de Janeiro: 7Letras: Faperj, 2014a.

MELO, Victor Andrade de; PERES, Fabio de Faria. 0 corpo da nação: posicionamentos governamentais sobre a Educação Física no Brasil monárquico. História, Ciência e Saúde, Rio de Janeiro, v. 21, n. 4, p. 1131-1150, out./dez. 2014b.

MELO, Victor Andrade de; PERES, Fabio de Faria. Relações entre ginástica e saúde no Rio de Janeiro do século XIX: reflexões a partir do caso do Colégio Abílio, 1872-1888. História, Ciência, Saúde, Rio de Janeiro, v. 23, n. 4, p. 1133-1151, dez. 2016b.

MORMÊLLO, Ben Hur. 0 ensino de matemática na Academia Real Militar do Rio de Janeiro, de 1811 a 1874. 2010. Dissertação (Mestrado Profissional em Matemática) - Universidade Estadual de Campinas, Campinas, 2010.

NEVES, Lucia Bastos Pereira das. A vida política. In: SILVA, Alberto da Costa (Coord.). História do Brasil Nação (1808-2010). crise colonial e independência (1808-1830). v. 1. Rio de Janeiro: Objetiva, 2011. p. $75-114$. 
O AMERICANO, Rio de Janeiro, 7 fev. 1849.

O AMERICANO, Rio de Janeiro, 20 abr. 1850.

O PHAROL CONSTITUCIONAL, Rio de Janeiro, 23 ago. 1844.

PANIZZOLO, Claudia. João Kopke e a escola republicana: criador de leituras, escritor da modernidade. 2006. Tese (Doutorado em Educação) - Pontifícia Universidade Católica de São Paulo, São Paulo, 2006.

REVISTA MEDICA BRASILEIRA, Rio de Janeiro, 1841.

REVISTA POPULAR, Rio de Janeiro, 1859.

RIOS FILHO, Adolfo Morales de los. 0 Rio de Janeiro imperial. Rio de Janeiro: Topbooks, 2000.

SANCHES, António Ribeiro. Cartas sobre educação da mocidade. Covilhã: Universidade da Beira do Interior, 2003. Disponível em: <www.estudosjudaicos.ubi.pt/rsanches_obras/cartas_educacao_mocidade.pdf>. Acesso em: 25 jan. 2017.

SCHWARCZ, Lilia Moritz. Cultura. In: SILVA, Alberto da Costa (coord.). História do Brasil Nação (1808-2010). crise colonial e independência (1808-1830). v. 1. Rio de Janeiro: Objetiva, 2011. p. 205-248.

SEMANA ILUSTRADA, Rio de Janeiro, 30 mar. 1862.

VIGARELLO, Georges. A história e os modelos do corpo. Pró-Posições, Campinas, v. 14, n. 2, p. 21-29, maio/ago. 2003.

VIGARELLO, Georges; HOLT, Richard. 0 corpo trabalhado: ginastas e esportistas no Século XIX. In: CORBIN, Alain; COURTINE, Jean-Jacques; VIGARELLO, Georges (Org.). História do corpo. v. 2. Petrópolis: Vozes, 2008. p. 393-478.

VIÑA0, Antonio. História das disciplinas escolares. Revista Brasileira de História da Educação, Maringá, n. 18, p. 174-216, 2008.

VINCENT, Guy; LAHIRE, Bernard; THIN, Daniel. Sobre a história e a teoria da forma escolar. Educação em Revista, Belo Horizonte, n. 33, p. 7-47, jun. 2011.

Recebido em: 15.02.2017

Aprovado em: 23.05.2017

Victor Andrade de Melo é professor nos programas de pós-graduação em Educação e em História Comparada. É coordenador do Sport: Laboratório de História do Esporte e do Lazer. É bolsista de Produtividade em Pesquisa (CNPq) e Cientista de Nosso Estado (Faperj). 